\title{
Keratin degrading microbial keratinase as a tool for bioremediation
}

\begin{abstract}
Most of the hard-to-degrade keratin containing substrates like feathers or animal hairs is either discarded or incinerated, resulting in energy consumption and environmental pollution. Thus, an innovative eco-friendly method to deal with these wastes is urgently needed. Microbial degradation of keratin by keratinases has gained biotechnological interest in applications and represents a great opportunity to manage waste materials with no adverse impacts. This article deals with the importance of keratinase and its ongoing applications that can be further used in future to sustain environment.
\end{abstract}

Keywords: microbial keratinase, bioremediation, tanning, dehairing, prion degradation
Volume 5 Issue 4 - 2017

\section{Roohi,' Mohammed Kuddus²}

'Department of Bioengineering, Integral University, India

${ }^{2}$ Department of Biochemistry, University of Hail, Saudi Arabia

Correspondence: Mohammed Kuddus, Department of Biochemistry, University of Hail, Hail, Saudi Arabia, Email roohi0607@gmail.com

Received: May 12, 2017 | Published: July 31, 2017

\section{Introduction}

Proteolytic enzymes covers almost $40 \%$ worldwide sale and majority are used at industrial scale. ${ }^{1}$ Keratinase (EC 3.4.99.11) is a member of protease family and of high importance as involved in cleaning the environment. ${ }^{2}$ Keratinase works on keratin protein (present mostly in hair, hooves, horns, wool, feather, nails and other epithelial covers of vertebrates) which are highly super coiled protein and are unable to be digested by normal pepsin, trypsin and papain enzymes. Despite the intractable nature of keratin, it contain good amount of essential amino acids which can be utilized for manufacturing of feedstuffs, organic fertilizers, biodegradable films, glues and foils. ${ }^{3}$ These slow releasing nitrogen fertilizer containing keratinase is environment friendly and reduces the costs of commercial fertilizers. The chief source of such organic fertilizers is feathers which are waste-product produced annually $\sim 350$ million tons alone in India from the production unit of chicken meat. This waste disposal problem can be overcome by using keratinase enzyme where microbial keratinase produced by bacteria won the race in degradation ability of keratin protein as compared to yeast and fungi. ${ }^{2}$ As reported by Odetallah et al.4 use of Bioresource International's (BRI), Versazyme in feather meal production has been commercialized which is the first commercial keratinase that declared to turn chicken feathers into dollars. As far reported in the literature, isolates belonging to the Bacillus and Streptomyces genera seem to offer a significantly greater diversity and a wide range of advantage of keratinase including accelerated accumulation of biomass and enzymes. ${ }^{5}$ Potential keratinase producing strains are B. pumilus NRC21,1 Bacillus licheniformis and Bacillus subtili , ${ }^{6,7}$ Bacillus $s p .8$ Bacillus tequilensis Q7,9 Meiothermus sp. I40. ${ }^{10}$ fungi such as Aspergillus, Absidia and Rhizomucor; ${ }^{3}$ some species of dermatophytes, including Trichophyton mentagrophytes, T. rubrum, T. Gallinae, Microsporium canis and M. Gypseum, ${ }^{11}$ a few actinomycetes such as Streptomyces pactum, S. albus. ${ }^{11}$

One of the potential, promising and eco-friendly applications of keratinase is in animal hide bating in the leather processing industry which is one of the oldest and fast-growing industries in the world and plays a significant role in today's economic global economy. Bating is one of the important measures used for removing epidermal proteins from animal hide or skin that gives clean, smooth, fine and stable leather that improves its quality. ${ }^{12}$ The ultimate goal of the bating process is to make hides pliable and prepare them for the tanning process. Traditional bating methods employed use of sodium sulphide and lime and/or animal wastes, including dog feces and pigeon droppings. Although giving satisfactorily results, these methods are coupled with unpleasant odor and toxic working area for the workers. On the contrary when bating is achieved by microbial keratinase then end-product quality enhances, odor/toxicity level minimizes and environmental pollution reduces. Furthermore, a recent patent proposed a concrete mixture of dehairing enzymes from B. subtilis and B. cereus with sodium carbonate, caustic soda and thioglycolic acid has also been reported. ${ }^{9}$

Literature survey shows that alkaline proteases, in general keratinase known as "green chemicals" have made their way as key-ingredient in detergent formulations as well. ${ }^{13}$ They are used as additives for cleaning up of drains clogged with keratinase wastes and also to improve the wash performance of enzyme-based laundry detergents. ${ }^{14}$ Very recent Sanghvi et al. ${ }^{1}$ proposed the use of keratinase inclusion in formulation of hair removal cream. Such creams are basically chemical depilatory in action where chemical thioglycolate mixed with sodium hydroxide or calcium hydroxide is used to dissolve the hair from skin epidermis. But here replacement of chemically toxic substance with purified alkaline keratinase isolated from B. subtilis DP1 species Sanghvi et al. ${ }^{1}$ makes the hair removal cream organic, safe and non-allergenic. Consistent innovation and new applications of keratinase attracted the attention of researcher for global use of this enzyme. Many applications of keratinase are still in the early stages like prion degradation for treatment of mad cow disease, 8 biodegradable plastic manufacturing and keratin peptides production. ${ }^{15}$ Still, the industrial applications and hence the market demand of keratinases as compared to other industrial enzymes are still in the stage of infancy and effort should be directed to reduce the keratinase production cost.

\section{Conclusion}

Ubiquitous keratinase enzyme has the capability that replaces most of the conventional proteases in the leather industry and detergent additive application due to their better performance. Moreover cost effective production of keratinase can be achieved by using keratinous waste biomass through fermentation that reduces the environmental waste load as well. The advent of keratinase has given new direction for waste management with industrial applications for sustainable development. 


\section{Acknowledgements}

None.

\section{Conflicts of interest}

The authors declare that there is no conflict of interest.

\section{References}

1. Sanghvia G, Patela H, Vaishnava D, et al. A novel alkaline keratinase from Bacillus subtilis DP1 with potentialutility in cosmetic formulation. Int J Biologic Macromol. 2016;87:256-262.

2. Agrahari S, Wadhwa N. Degradation of chicken feather a poultry waste product by keratiniolytic bacteria isolated from dumping site at Ghazipur poultry processing plant. Int J Poul Sci. 2010;9(5):482-489.

3. Friedrich J, Gradisar H, Mandin D, et al. Screening fungi for synthesis of keratinolytic enzymes. Lett Appl Microbiol. 1999;28(2):127-130.

4. Odetallah NH, Wang JJ, Garlich JD, et al. Versazyme supplementation of broiler diets improves market growth performance. Poultry Science. 2005;84(6):858-864.

5. Lucas FS, Broennimann O, Febbraro I, et al. High diversity among feather-degrading bacteria from a dry meadow soil. Microb Ecol. 2003;45(3):282-290.

6. Dettmer A, Cavalli E, Ayub MA, et al. Optimization of the unhairing leather processing with enzymes and the evaluation of inter-fibrillary proteins removal: an environment-friendly alternative. Bioprocess Biosyst Eng. 2012;35(8):1317-1324.

7. Gupta R, Rajput R, Sharma R, et al. Biotechnological applications and prospective market of microbial keratinases. Appl Microbiol Biotechnol. 2013;97(23):9931-9940.
8. Brandelli A. Bacterial keratinase: useful enzyme for bioprocessing agroin- dustrial waste and beyond. Food Bioprocess Technol. 2008;1(2):105-116.

9. Jaouadia NZ, Rekika H, Elhoula MB, et al. A novel keratinase from Bacillus tequilensis strain Q7 with promising potential for the leather bating process. In J Biologic Macromol. 2015;79:952-964.

10. Kuo JM, Yang J, Chen W, et al. Purification and characterization of a thermostable keratinase from Meiothermus sp. I40. Inter Biodeter Biodegrad. 2011;70:111-116.

11. Bockle B, Galunski B, Muller R. Characterization of a keratinolytic serine protease from Streptomyces pactum DSM40530. Appl Environ Microbiol. 1995;61(10):3705-3710.

12. $\mathrm{Hu} \mathrm{H}, \mathrm{Gao} \mathrm{J}, \mathrm{He} \mathrm{J}$, et al. Codon optimization significantly improves the expression level of a keratinase gene in Pichia pastoris. PLOS ONE. 2013;8(3):e58393.

13. Rai SK, Mukherjee AK. Optimization of production of an oxidant and detergent-stable alkaline keratinase from Brevibacillus sp. strain ASS10-II: Application of enzyme in laundry detergent formulations and in leather industry. Biochem Engi J. 2011;54:47-56.

14. Farag AM, Hasan MA. Purification, characterization and immobilization of a keratinase from Aspergillus orizae. Enzyme Microbiol Technol. 2004;34(2):85-93.

15. Vermelho AB, Vazquez Villa AL, de Almeida AMM, et al. Keratin hydrolysates, process for their production and cosmetic composition containing the same. United States Patent 20100196302A1, USA. 2010. 